\title{
Biodegradable Compounds of Poly (E-Caprolactone)/Montmorillonite Clays
}

\author{
Danilo Diniz Siqueira ${ }^{\star} \mathbb{D}^{\circ}$, Carlos Bruno Barreto Luna ${ }^{\circledR}$, Edcleide Maria Araújo $^{a}{ }^{\mathbb{D}}$, Edson Antônio

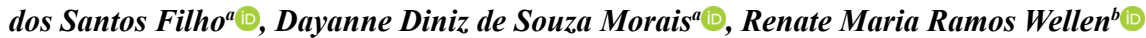 \\ ${ }^{a}$ Universidade Federal de Campina Grande, Departamento de Engenharia de Materiais, CEP 58429-900, \\ Campina Grande, PB, Brasil \\ ${ }^{b}$ Universidade Federal da Paraíba, Departmento de Engenharia de Materiais, João Pessoa, CEP 58051-085, \\ $P B$, Brasil
}

Received: December 08, 2018; Revised: September 21, 2019; Accepted: November 25, 2019

\begin{abstract}
Biodegradable Poly ( $\varepsilon$-caprolactone) (PCL) was compounded with Brasgel PA(MMT) and Cloisite $\mathrm{Na}(\mathrm{CLNa})$, and compatibilized with maleic anhydride grafted poly( $\varepsilon$-caprolactone) (PCL-g-MA). No evidence of degradation was verified during processing, as well as particle aggregates were absent as displayed through scanning electron microscopy (SEM) images. Compatibilized compounds upon clay addition achieved higher thermal stability as visualized by thermogravimetry (TG). Montmorillonite clays acted as nucleant agent during PCL melt crystallization as evidenced by differential scanning calorimetry (DSC). Mechanical behavior of PCL was preserved, and all compounds presented Elongation higher than $350 \%$ meanwhile the heat distortion temperature (HDT) was increased by $20 \%$ in PCL compounds, which may have wider range of application and better performance.
\end{abstract}

Keywords: Poly (ع-caprolactone), montmorillonite clays, PCL-g-MA, thermal and morphological properties.

\section{Introduction}

Nowadays, society is concerned in how to preserve the environment wellbeing, scientists and researchers have focused their attention on finding solutions to the large amounts of waste that are daily produced, mainly, due to the use of quickly discarded products. In this sense, sustainable methods have been developed to stimulate "green technologies", that is, development of materials that favor the closed life cycle, producing biodegradable waste without damaging to ecosystems. ${ }^{1,2}$

Biodegradable polymers can be decomposed in bioactive environments through microorganisms' action. There are several advantages in using these polymers, such as increased soil fertility, lower accumulation of plastic products in landfills and lower costs in waste management, for instance. ${ }^{3,4}$

In this work poly ( $\varepsilon$-caprolactone) (PCL) compounds were investigated; PCL is a linear, biodegradable and biocompatible aliphatic polyester commonly used in pharmaceuticals and dressings for wounds. ${ }^{5,6}$ PCL is synthesized through $\varepsilon$-caprolactone ring-opening polymerization or by free-radical polymerization of 2-methylene-1,3-dioxepane. ${ }^{7-9}$

Biodegradable polymers can be used in blends, composites and nanocomposites. However, for an effective compatibilization between components, the best strategy used has been the incorporation of graft copolymers as compatibilizers in original incompatible systems. Methods used to obtain these compatibilizers include chemical modification of non-polar polymers with monomers by reactive processing, such as maleic anhydride (MA). ${ }^{10,11}$

Grafting with maleic anhydride is intended to achieve compatibility between polymers in blends or between filler

*e-mail: danilodinizsiqueira@gmail.com and polymer in composites or nanocomposites. Reactions are usually performed in presence of organic peroxides and can take place in solid, melt or solution states. The reaction in the melt, by reactive processing, has been the most used method due to lower cost and easy operation. ${ }^{12,13}$ Continuous or discontinuous mixing equipment can be used as a reactive chemical reactor, maleic anhydride grafting reactions with peroxides were performed on both torque rheometers and single and double screw extruders. During reactive extrusion, polymer modification reactions and processing take place simultaneously. ${ }^{9,12}$

Adding clays in polymer compounds has been a common practice due to the improvement of several properties, such as permeability and thermal resistance. Single characteristics presented by mineral clays as: lamellar or fibrous structures, ion exchange capacity, wide range of chemical composition as well as electric charge of lamellae; provide special physicochemical behaviors that determine their surface properties and interactions in organic substances, such as polymers. ${ }^{14,15}$

This work aims at the development of biodegradable compounds based on PCL produced in an internal mixer, maleic anhydride grafted poly( $\varepsilon$-caprolactone) (PCL-g-MA) is added as compatibilizer, and montmorillonite clays Brasgel PA (MMT) and Cloisite $\mathrm{Na}$ (CL Na) as fillers.

\section{Methodology}

\subsection{Materials}

Poly ( $\varepsilon$-caprolactone) (PCL), Capa ${ }^{\circledR}$ 6500, with $\mathrm{IF}=7.9 \mathrm{~g} / 10 \mathrm{~min}\left(160^{\circ} \mathrm{C} / 2.16 \mathrm{~kg}\right)$ from Perstorp Winning Formulas. The clays were Brasgel PA, coded as MMT and Cloisite $\mathrm{Na}$, coded as CLNa, supplied by Bentonit União Nordeste (BUN), located in Campina Grande/PB/Brazil. 
The copolymer PCL-g-MA used as compatibilizer was produced by Siqueira et al. ${ }^{16}$.

\subsection{Grafting MA groups onto PCL}

This work was based on the studies of Siqueira et al. ${ }^{16}$, where the selected parameters were those that presented the best conditions for processing and functionalization of poly ( $\varepsilon$-caprolactone) with maleic anhydride (MA). Functionalization was performed in a Thermocientific Polylab QC torque rheometer, operating at $160^{\circ} \mathrm{C}, 60 \mathrm{rpm}$ for $10 \mathrm{~min}$. The functionalized copolymer was synthesized at $1.0 \%$ content of initiator dycumil peroxide (DCP) and $5.0 \%$ of maleic anhydride.

\subsection{Purification of Functionalized Polymer}

Modified poly ( $\varepsilon$-caprolactone) was purified for taking out residual monomers and other possible by-products. Part of grafted polymer was dissolved in xylene at $120^{\circ} \mathrm{C}$ under stirring and refluxed for 3-4 h. The solution was filtered and precipitated. After this procedure, the material was dried under vacuum for $24 \mathrm{~h}$ at $40^{\circ} \mathrm{C}$. This procedure also was used by Siqueira et al. ${ }^{16}$.

The anhydride content in the grafted polymer was determined by titration of the acid groups derived from the anhydride functions using the procedure described by John et al. ${ }^{17}$ and used by Siqueira et al. ${ }^{16}$, where the extracted sample was refluxed for $1 \mathrm{~h}$ in xylene saturated with water. The solution was titrated with $0.05 \mathrm{~N}$ ethanoic $\mathrm{KOH}$ using $1 \%$ drops of thymol blue in dimethylformamide as an indicator. An excess of $\mathrm{KOH}$ was added and the dark blue color was titrated through a yellow end point by addition of $0.05 \mathrm{~N}$ isopropanic hydrochloric acid. PCL-g-MA was completely soluble in water-saturated xylene and did not precipitate during titration.

\subsection{Compounding in the Internal Mixer}

PCL/MMT, PCL/PCL-g-MA/MMT, PCL/CLNa and PCL/PCL-g-MA/CLNa systems were compounded in a Thermocientific Polylab QC torque rheometer in contents as described in Table 1. Previously, compounds were cold mixed and then fed into the mixer chamber. Compounds were processed at $160^{\circ} \mathrm{C}, 60 \mathrm{rpm}$ for $10 \mathrm{~min}$.

Table 1. Composition of PCL compounds.

\begin{tabular}{lcccc}
\hline Composition & $\begin{array}{c}\text { PCL } \\
(\%)\end{array}$ & $\begin{array}{c}\text { PCL-g- } \\
\text { MA (\%) }\end{array}$ & $\begin{array}{c}\text { MMT } \\
(\%)\end{array}$ & $\begin{array}{c}\text { CL } \\
\mathbf{N a} \\
(\%)\end{array}$ \\
\hline PCL & 100 & - & - & - \\
PCL + MMT & 97 & - & 3 & - \\
PCL + CLNa & 97 & - & - & 3 \\
PCL + PCL-g-MA + & 92 & 5 & 3 & - \\
MMT & & & & \\
PCL + PCL-g-MA+ & 92 & 5 & - & 3 \\
CLNa & & & & \\
\hline
\end{tabular}

\subsection{Extrusion}

Initially, a concentrate of PCL/MMT and PCL/CLNa was processed using a high-speed homogenizer $\mathrm{MH}-50 \mathrm{H}$ from MH. Compounds with 1:1 PCL/Clay were homogenized. Afterwards the concentrates were crushed in a knife mill.

PCL and concentrates were processed in a Coperion (Werner-Pfleiderer ZSK 18) double screw extruder (Wesseling, Rhein-Erft-Kreis, Germany) under processing parameters presented in Table 2 . The polymer/clay concentrates were incorporated into PCL, in nominal content of $3 \%$ by weight of clay, under the same processing parameters applied for neat PCL.

With the extrudate, injected specimens were produced according to ASTM D638 (Type I), D256 and D648, for tensile, impact and HDT tests, respectively. Specimens were made using an Arburg Allrounder 270C Golden Edition, operating at $110^{\circ} \mathrm{C}$, with mold at $20^{\circ} \mathrm{C}$. An average of 10 specimens was used for each investigated composition.

\subsection{Characterizations}

For torque rheometry analyses a Rheocord 600 coupled to a Haake System 90 was used, with roller type rotors operating at $60 \mathrm{rpm}$ and $160^{\circ} \mathrm{C}$, under an air for 10 minutes. Analyses were done in duplicates.

The $\mathrm{X}$ ray diffraction (XRD) experiments carried out in a Bruker D2Phaser, using copper $\mathrm{K} \alpha$ radiation, voltage of 40 $\mathrm{kV}$, current of $30 \mathrm{~mA}$, scanning from 2 to $30^{\circ}$ and scanning speed of $0.2 \% \mathrm{~min}$.

Fourier-transform infrared spectroscopy (FTIR) was performed in a Bruker - Vertex 70 Spectrometer, with scans from 4000 to $450 \mathrm{~cm}^{-1}$. Experiments were executed using impact specimens.

Thermogravimetric (TG) analyzes were performed in a TGA $51 \mathrm{H}$ Shimadzu, using $5 \pm 0.5 \mathrm{mg}$ of sample. The heating rate used was $10^{\circ} \mathrm{C} / \mathrm{min}$, from room temperature $\left(23^{\circ} \mathrm{C}\right)$ to $500^{\circ} \mathrm{C}$, under inert nitrogen atmosphere, at gas flow rate of $50 \mathrm{~mL} / \mathrm{min}$.

Differential scanning calorimetry (DSC) analyzes were performed in a Shimadzu DSC-50, samples were heated from room temperature $\left(23^{\circ} \mathrm{C}\right)$ to $150^{\circ} \mathrm{C}$, and then cooled to room temperature at a heating/cooling rate of $10^{\circ} \mathrm{C} / \mathrm{min}$, under nitrogen atmosphere with gas flow rate of $50 \mathrm{~mL} / \mathrm{min}$.

The tensile tests carried out according to ASTM D 638, Elastic Modulus, Tensile Strength and Elongation were measured. The tests were performed in a universal EMIC model DL10000, using a load cell of $200 \mathrm{kgf}$, with deformation of $50 \mathrm{~mm} / \mathrm{min}$, operating at room temperature. Presented results are an average of 10 tests.

The IZOD impact strength tests were performed on notched specimens, using a Resil 5.5 from Ceast and a pendulum of $2.75 \mathrm{~J}$, according to ASTM D 256, at room temperature. Presented results are an average of 10 tests.

Heat deflection temperature (HDT) was obtained according to ASTM D 648, in a Ceast HDT 6 VICAT/N 6921.000, 
Table 2. Processing parameters for neat PCL and compounds.

\begin{tabular}{|c|c|c|c|c|c|c|c|}
\hline Parameters & Zone 1 & Zone 2 & Zone 3 & Zone 4 & Zone 5 & Zone 6 & Zone 7 \\
\hline Temperature $\left({ }^{\circ} \mathrm{C}\right)$ & 80 & 90 & 110 & 160 & 160 & 160 & 160 \\
\hline Screw rate (rpm) & & & & \multicolumn{4}{|c|}{200} \\
\hline Torque (\%) & & & & \multicolumn{4}{|c|}{$50-55$} \\
\hline Feed flow $(\mathrm{kg} / \mathrm{h})$ & & & & \multicolumn{4}{|c|}{3} \\
\hline
\end{tabular}

with a tension of $455 \mathrm{kPa}$, heating rate of $120^{\circ} \mathrm{C} / \mathrm{h}$ (method A). The temperature was determined after the sample had deflected $0.25 \mathrm{~mm}$. Presented results are an average of 3 tests.

Scanning electron microscopy (SEM) images were captured from injected fractured surface using a Tescan Veja 3 at a voltage of $30 \mathrm{kV}$ under high vacuum. Specimens were gold covered using a sputtering - metallic Shimadzu - IC 50 , using a current of $4 \mathrm{~mA}$ for 2 minutes.

\section{Results and Discussion}

\subsection{Torque Rheometry}

Figure 1a presents torque versus time plots of PCL, PCL/ MMT, PCL/PCL-g-/MMT, PCL/CLNa and PCL/PCL-g-MA/ CLNa compounded in the internal mixer for 10 minutes and $160^{\circ} \mathrm{C}$, in the right side of Figure $1 \mathrm{~b}$ is shown torque versus time plots for the interval 6-10 minutes, when the constant plateau was reached.

Torque rheometry was used to investigate the thermal stability of PCL compounds during processing. As torque is directly proportional to viscosity, under constant processing parameters, i.e., temperature and rotor speed, torque results can be understood as an indirect measure of molecular weight. At constant temperature torque dropping means decreasing in molecular weight, suggesting that compounds degradation occurred during processing. A constant torque plateau indicates absence of degradation as observed in Figure 1a. ${ }^{18}$

It can be observed in Table 3 that neat PCL has an average torque of 2.90 N.m. In general, upon clay addition, compounds

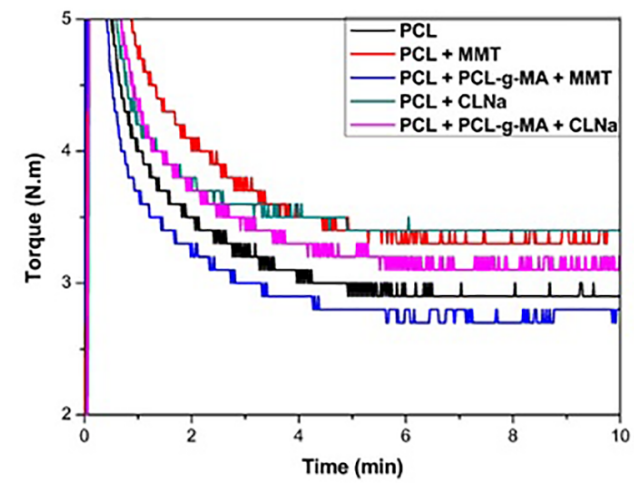

(a) 0-10 minutes viscosity increases, as expected, due to the interaction among clay lamellae and entangled macromolecular chains. Thus, indicating there was an increase in friction or shear rate during compounding. ${ }^{19}$

Table 3. Torque of PCL compounds.

\begin{tabular}{lcc}
\hline Compound & $\begin{array}{c}\text { Mean Torque } \\
(\mathrm{N} . \mathrm{m})\end{array}$ & $\begin{array}{c}\text { Standard } \\
\text { Deviation (N.m) }\end{array}$ \\
\hline PCL & 2.90 & \pm 0.02 \\
PCL/MMT & 3.33 & \pm 0.04 \\
PCL/PCL-g-MA/MMT & 2.75 & \pm 0.05 \\
PCL/CLNa & 3.40 & \pm 0.01 \\
PCL/PCL-g-MA/CLNa & 3.13 & \pm 0.05 \\
\hline
\end{tabular}

Brito et al. ${ }^{20}$ investigated the rheological behavior of PE/ PE-g-MA/Bentonite clay by torque rheometry, as PE-g-MA has a polar structure, interaction evidences between clay and PE were verified, resulting in higher torque values. In the present work, as PCL already presents a polar structure Gorrassi et al. ${ }^{21}$, Wu and Liao, ${ }^{22}$ suggest upon clay addition, its most like interactions take place even in the absence of PCL-g-MA, providing increased torque of both compositions, i.e., compounds with MMT and CLNa.

Subtle differences between viscosity compounds with MMT and CLNa are most due from exchangeable cation linkages. In this case, CLNa would have higher bond energy than MMT. ${ }^{23-25}$ Meanwhile, compatibilizer addition to PCL/clay compounds slightly reduced the torque, probably due to the compatibilizer acting as a solvent or plasticizer, thus decreasing the viscosity.

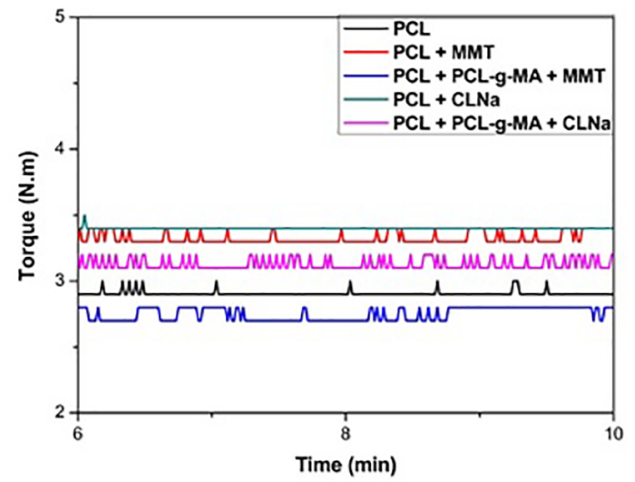

(b) 6-10 minutes

Figure 1. Torque versus time for PCL, PCL/MMT, PCL/PCL-g-/MMT, PCL/CLNa and PCL/PCL-g-MA/CLNa compounds Figure 1a. Constant plateau for the interval time ranging from 5 to $10 \mathrm{~min}$ Figure $1 \mathrm{~b}$. Compounding parameters: $160^{\circ} \mathrm{C}, 60 \mathrm{rpm}, 10 \mathrm{~min}$. 


\section{$3.2 X$-ray diffraction $(X R D)$}

Figure 2 shows X-ray diffractograms of MMT and CLNa, and Figure 3 presents X-ray diffractograms of PCL compounds.

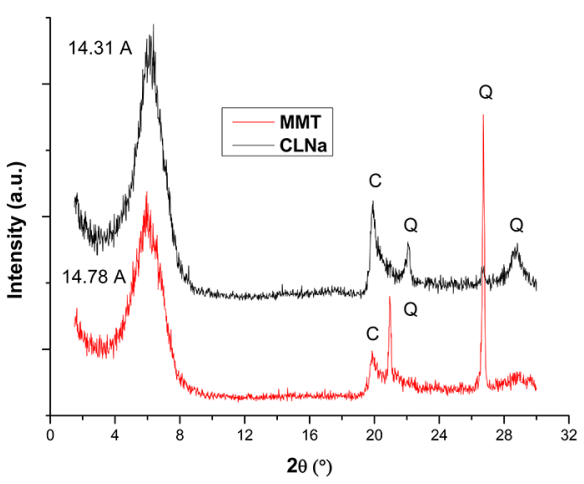

Figure 2. X-ray diffractograms of CLNa and MMT.

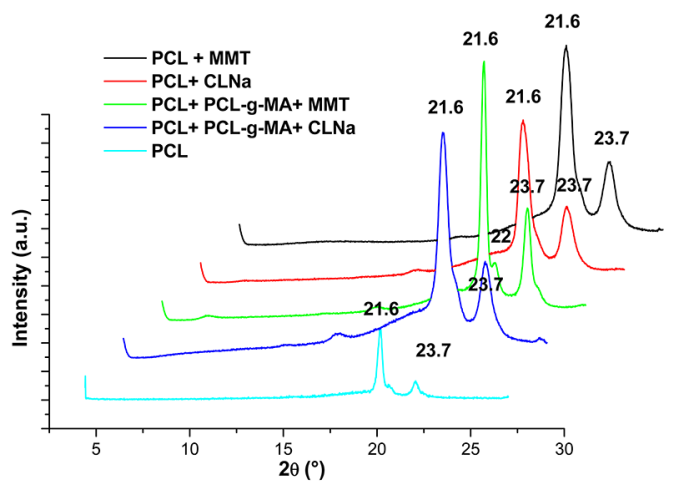

Figure 3. X-ray diffractograms of PCL compounds.

Diffractograms of CLNa and MMT display characteristic peaks of montmorillonite, which has accessory materials, such as kaolinite (C) and quartz (Q). CLNa presented an intense peak at $14.31 \AA$ and MMT at $14.78 \AA$, indicative of basal interplanar distances of $6.14^{\circ}$ and $5.91^{\circ}$, similar results were reported by Souza Santos ${ }^{26}$, Paz et al. ${ }^{27}, \mathrm{Kojuch}^{28}$ and Leite et al. ${ }^{29}$.

$\mathrm{XRD}$ is a powerful technique to observe the degree of clay dispersion as well as the disorder degree of clay's crystalline structure in polymeric compounds, in this present work in PCL compounds. Generally intense reflections in the range of $2 \theta=$ $3-10^{\circ}$ indicate an intercalated ordered system with alternating layers of polymer/silicate. On the other hand, when exfoliation is achieved, i.e. when individual silicate layers ( $1 \mathrm{~nm}$ thick) are homogeneously dispersed in the matrix, the XRD diffractograms do not show peaks due to loss of clay's structural identity. ${ }^{24}$

In diffractograms of Figure 3 can be verified that no composition presented peaks due to MMT and CLNa clays. This can be an indicative of an exfoliated structure, that is, disordering is suggested in the clay's stacking layers, increasing their basal spacing between the lamellae, thus making it difficult to evaluate the diffraction angle $2 \theta \cdot{ }^{30}$ In addition, can be observed PCL crystalline character did not change after addition of MMT and CLNa.

which refer to the segments of chains that bend in an orderly manner generating crystalline palms at (110)

Diffractograms in Figure 3 illustrate that all compounds presented two characteristic peaks associated to PCL, at $2 \theta$ $=21.6^{\circ}$ and $2 \theta=23.7^{\circ}$, which are due to chain segments ordering bending providing crystalline plans at (110) e (200). The peak at $2 \theta=22.0^{\circ}$ is believed to be characteristic of the compatibilizer maleic anhydride (MA), as also reported by Vertuccio et al. ${ }^{31}$, Gautam et al. ${ }^{32}$ e Xing e Yang ${ }^{33}$.

\subsection{Spectroscopy in the Infrared Region with Fourier Transform (FTIR)}

Figure 4 presents FTIR spectra of MMT and CLNa clays, and PCL compounds. As expected, bands attributed to montmorillonite (the main mineral clay in bentonites) are observed in MMT and CLNa spectra in the region between $1004-1045 \mathrm{~cm}^{-1}$ characteristic of Si-O bonds, around 916 and $514 \mathrm{~cm}^{-1}$ corresponding to the octahedral layers of aluminosilicate $\mathrm{Si}-\mathrm{O}-\mathrm{Al}$, and around $3600 \mathrm{~cm}^{-1}$ due to the structural stretching vibrations of $\mathrm{OH}$ (hydroxyl) group. ${ }^{34}$

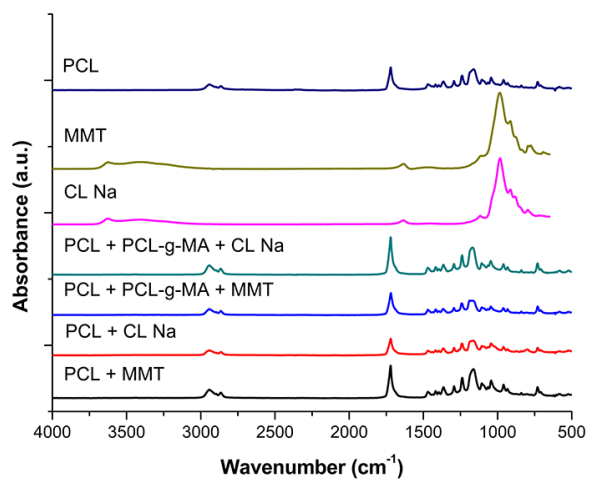

Figure 4. FTIR spectra of MMT and CLNa clays and PCL compounds.

Concerning PCL spectra, in general, there is no significant change in the compounds relative to neat PCL. It is also believed PCL peaks overlap the clays ones once they were not observed in the spectra.

In Figure 4 are observed bands in the range between 2943 and $2865 \mathrm{~cm}^{-1}$, which are attributed to asymmetric and symmetrical stretch of $\mathrm{CH}_{2}$; in $1720 \mathrm{~cm}^{-1}$ peaks are referred to carbonyl stretch $(\mathrm{C}=\mathrm{O})$ of PCL's ester group; bands in 1470 and $1366 \mathrm{~cm}^{-1}$ represent the stretching of $\mathrm{CH}$ groups in $\mathrm{CH}_{2}$; bands in 1241,1170 and $1294 \mathrm{~cm}^{-1}$ refer to the elongation in the crystalline phase of C-O and C-C linkages; in $1240 \mathrm{~cm}^{-1}$ asymmetric stretching of C-O-C; in $1170 \mathrm{~cm}^{-1}$ symmetrical stretching of C-O-C and in $1156 \mathrm{~cm}^{-1}$ elongation of $\mathrm{C}-\mathrm{O}$ and C-C linkages of PCL's amorphous phase. ${ }^{35}$

\subsection{Thermogravimetry (TG)}

Thermal stability of PCL compounds was investigated using thermogravimetry, Figure 5 displays TG plots. It is observed 
weight loss takes place in a single step for all PCL compounds, for neat PCL it starts $\sim 280^{\circ} \mathrm{C}$ whereas compounds with clay and PCL-g-MA have an onset temperature $\sim 350^{\circ} \mathrm{C}$. Upon addition of MMT and CLNa thermal stability of PCL was significantly increased, which may be provided to a likely protective barrier effect of the clay on the polymer, improving greatly its thermal resistance $^{36}$. Regarding the compatibilizer PCL-g-MA effect, it subtly decreased the weight loss onset temperature; this was most due its action as a solvent/plasticizer between PCL/Clays. ${ }^{37}$

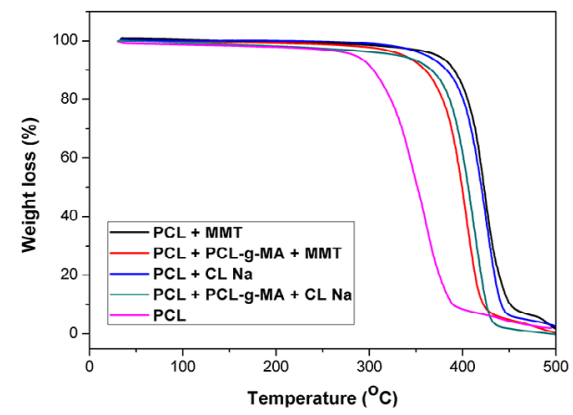

Figure 5. TG curves for PCL compounds.

\subsection{Differential Scanning Calorimetry (DSC)}

DSC scans acquired during cooling, i.e., during melt crystallization, of PCL compounds are presented in Figure 6a, bell shaped and single exotherms are observable. Upon clay addition the exotherms were displayed in higher temperatures, most likely to a nucleant action of clays, meanwhile the melting endotherms presented in the right side of Figure $6 \mathrm{~b}$ were not significantly affected being displayed in similar temperature ranges.

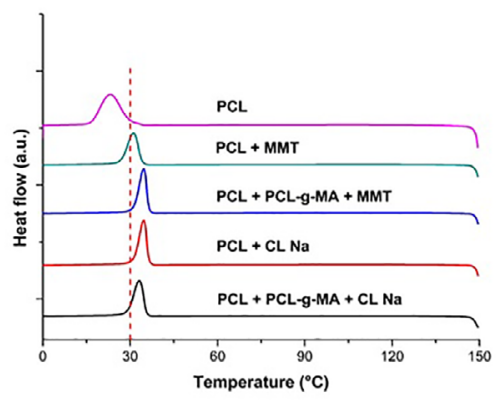

(a) Cooling

\subsection{Mechanical properties}

Mechanical properties of PCL compounds are presented in Table 4, regarding the Elastic Modulus an increase of $34.19 \%$ and $22.57 \%$ was observed for PCL/MMT and PCL/ CLNa, respectively, upon compatibilizer PCL-g-MA addition it increased by $18.31 \%$ and $20.69 \%$ in PCL/PCL-g-MA/ MMT and PCL/PCL-g-MA/CLNa. No significant effect was verified in Tensile Strength, whereas subtle decreases were observed in Maximum Elongation.

In general, polymer/clay systems with low nano-clay content $(<5 \%)$ often have higher mechanical properties when compared to the properties of neat polymers. The main reason for this higher performance is the strongest interfacial interaction between the matrix and the silicate layers compared to the reinforced systems with conventional loading. ${ }^{20,38}$

In principle, these results presented in this work are encouraging, since the use of nano-clays MMT and CLNa as lower cost filler was added in the PCL, providing an increase in thermal stability (TG) and Elastic Modulus without damaging the Tensile Strength.

Related to HDT an increase of $\sim 25 \%$ was observed in PCL compounds, which can be resulted from chemical interactions and well dispersed fillers in PCL matrix (see SEM images) due to successful processing. In general, adding nano-fillers in polymeric matrices increases their brittle character; an interesting result obtained in this work was the increase in HDT values, with no significant change in the Maximum Elongation whereas all compounds presented values higher than $350 \%$.

Regarding Impact Strength all the compounds had lower values than neat PCL, with higher decrease in MMT systems,

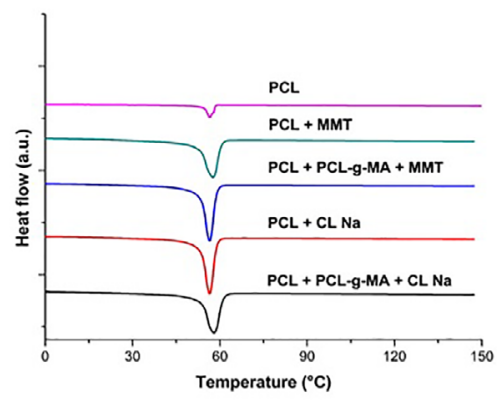

(b) Heating

Figure 6. DSC curves of PCL compounds. Melt crystallization acquired during cooling Figure 6a. Melting acquired during second heating Figure $6 \mathrm{~b}$.

Table 4. Mechanical properties of PCL compounds.

\begin{tabular}{lccccc}
\hline Compounds & $\begin{array}{c}\text { Elastic Modulus } \\
(\mathbf{M P a})\end{array}$ & $\begin{array}{c}\text { Tensile Strength } \\
(\mathbf{M p a})\end{array}$ & $\begin{array}{c}\text { Maximum } \\
\text { Elongation }(\%)\end{array}$ & $\begin{array}{c}\text { Impact Strength } \\
(\mathbf{J} / \mathbf{m})\end{array}$ & HDT $\left({ }^{\circ} \mathbf{C}\right)$ \\
\hline PCL & $171.10 \pm 16.50$ & $20.30 \pm 0.30$ & $>580.00^{*}$ & $178.50 \pm 4.40$ & $42.55 \pm 0.65$ \\
PCL/MMT & $260.85 \pm 2.57$ & $18.07 \pm 1.39$ & $449.37 \pm 42.25$ & $98.19 \pm 3.40$ & $54.10 \pm 0.63$ \\
PCL/CLNa & $221.02 \pm 2.13$ & $17.71 \pm 0.77$ & $370.20 \pm 10.50$ & $121.80 \pm 7.26$ & $53.40 \pm 0.80$ \\
PCL/PCL-g-MA/MMT & $209.46 \pm 3.08$ & $20.22 \pm 1.36$ & $562.16 \pm 51.99$ & $92.27 \pm 3.06$ & $53.50 \pm 0.63$ \\
PCL/PCL-g-MA/CLNa & $215.76 \pm 5.24$ & $18.99 \pm 0.08$ & $435.00 \pm 32.07$ & $100.85 \pm 5.46$ & $54.10 \pm 0.57$ \\
\hline
\end{tabular}


around $48.31 \%$ and $44.99 \%$ for compounds with PCL-gMA and without compatibilization. López et al. ${ }^{39}$ reported that impact strength is generally reduced upon increasing of maleic anhydride content in PP/montmorillonite clay.

PCL, as shown above, is a ductile polymer with higher impact strength, which is a measure of energy dissipation during short-term deformation in solid polymers. It is believed that in PCL/Clay compounds the added particles can act as stress concentrators preventing the proper energy dissipation mechanisms thus reducing the impact strength. ${ }^{40-42}$

\subsection{Scanning Electron microscopy (SEM)}

Figure 7 shows SEM images of neat PCL with evidence of extensive roughness characterizing ductile fracture with elastic and plastic deformation, thus providing fracture with high energy absorption, results that agree with those presented for maximum elongation in Table 2.
Figures 8 and 9 present SEM images for PCL/CLNa and PCL/MMT, respectively. Clearly, clay particles are observable in PCL; after fracturing, some particles remained adhered to PCL matrix meanwhile others pulled out from it. In general clay particles are well dispersed -as result of successful processing- in PCL promoting higher performance as above mentioned.

SEM images of compatibilized compounds are shown in Figures 10 and 11. A particulate structure embedded in PCL matrix is verified. Fibrils are also observed which act as anchor avoiding "pulling out" of clay particles, and this is an indication that there was interaction between matrix and reinforcement, i.e., PCL-g-MA/Clay, they are strong enough to increase the thermal stability as shown in TG thermograms and HDT while keeping good mechanical performance.

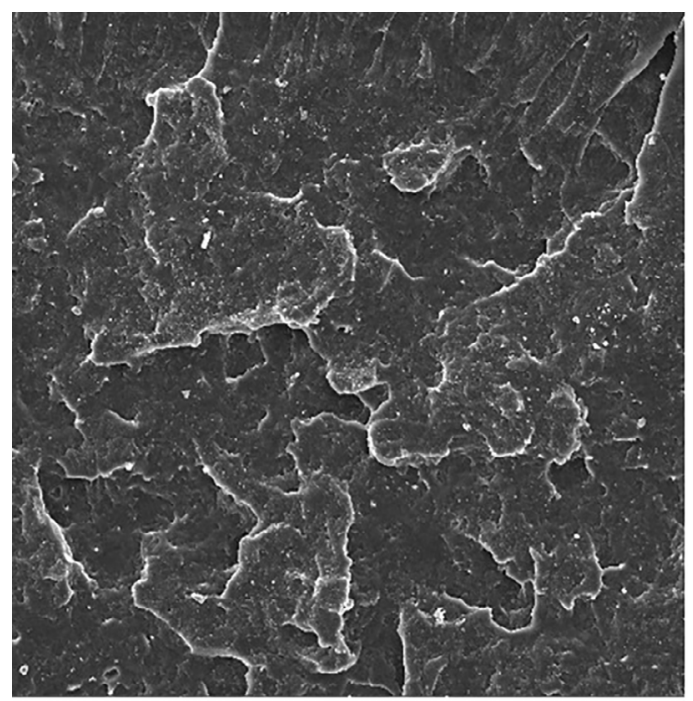

(a) $100 x$

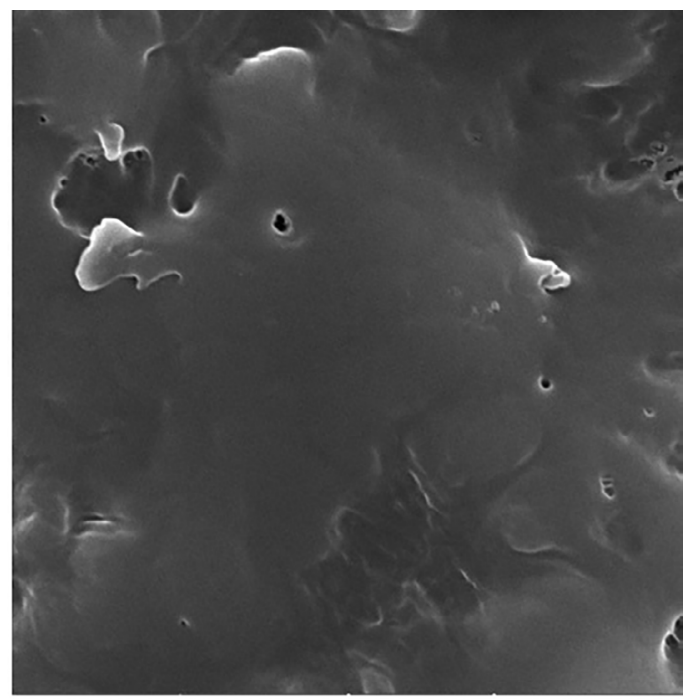

(b) $3000 x$

Figure 7. SEM images of neat PCL in different magnifications, on the Figure $7 \mathrm{a}$ with magnification of 100x and the Figure $7 \mathrm{~b}$ with magnification of $3000 x$.

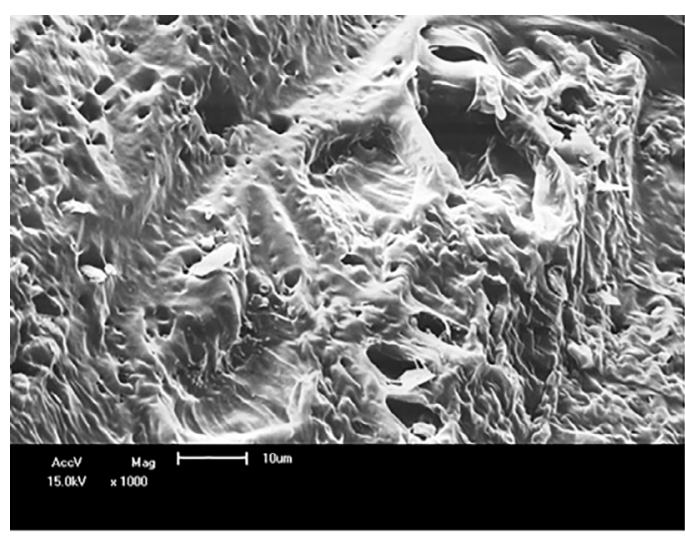

(a) $1000 x$

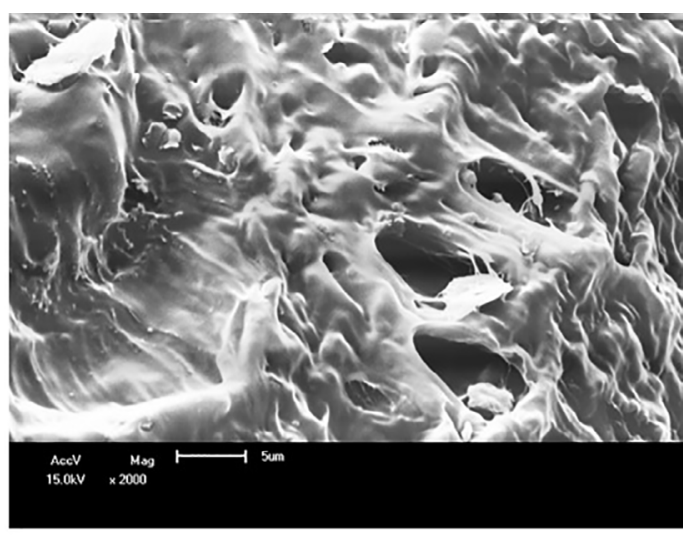

(b) $2000 x$

Figure 8. SEM images of PCL/CLNa in different magnifications, on the Figure 8a with magnification of 1000x and the Figure 8b with magnification of $2000 x$. 


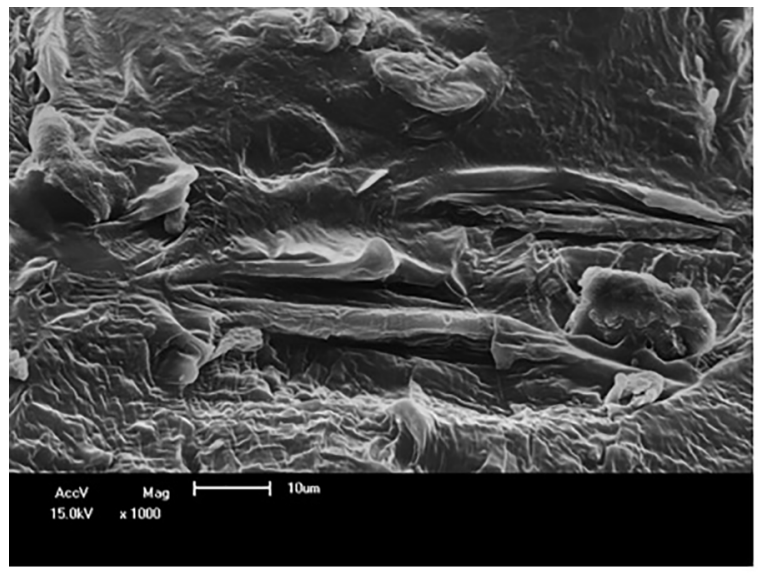

(a) $1000 x$

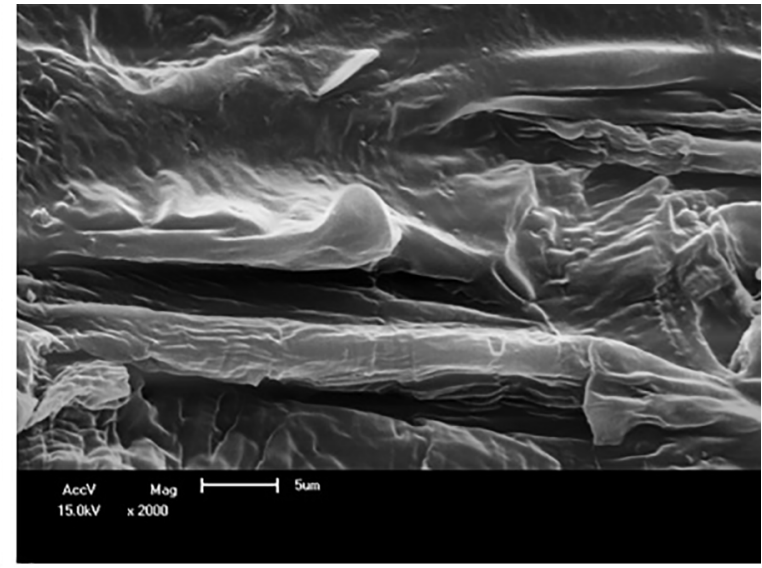

(b) $2000 x$

Figure 9. SEM images of PCL/MMT in different magnifications, on the Figure 9a with magnification of 1000x and the Figure 9b with magnification of $2000 x$.

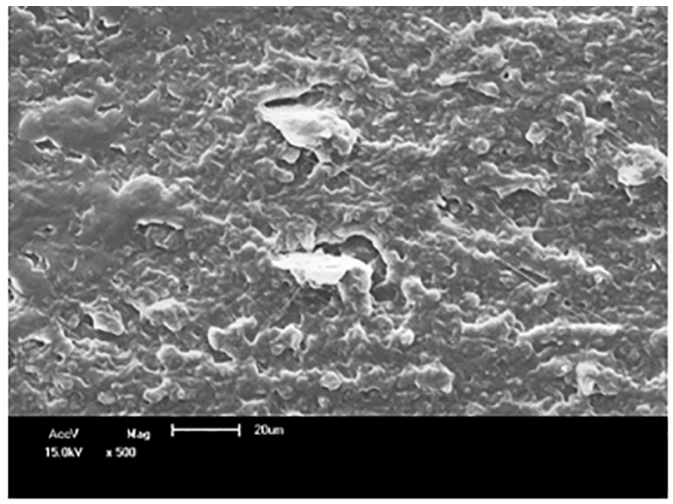

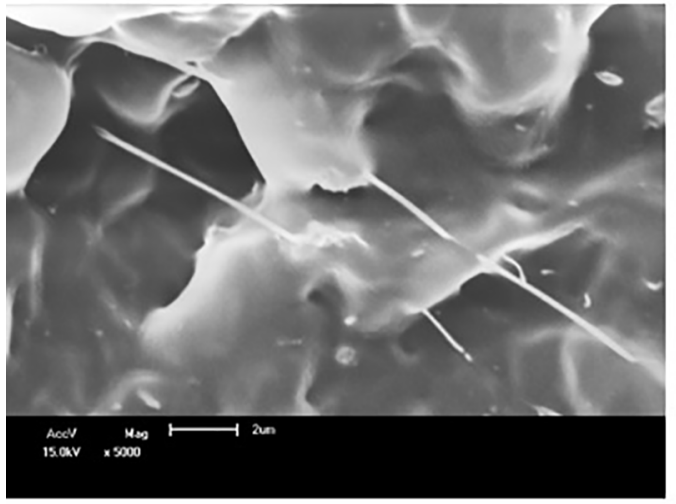

(b) $5000 x$

(a) $500 x$

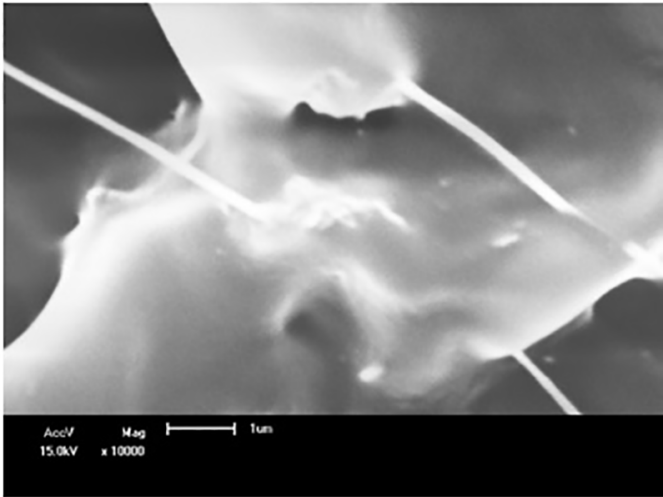

(c) $10000 x$

Figure 10. SEM images of PCL/PCL-g-MA/CLNa in different magnifications, Figure 10a 500x, Figure 10b 5000x and Figure 10c 10000x. 


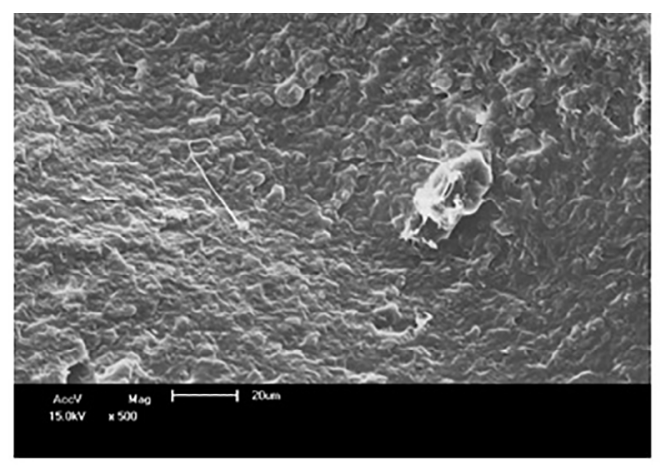

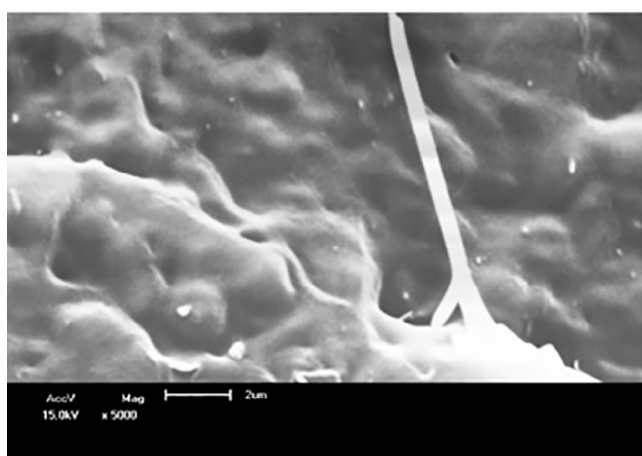

(b) $5000 \mathrm{x}$

(a) $500 x$

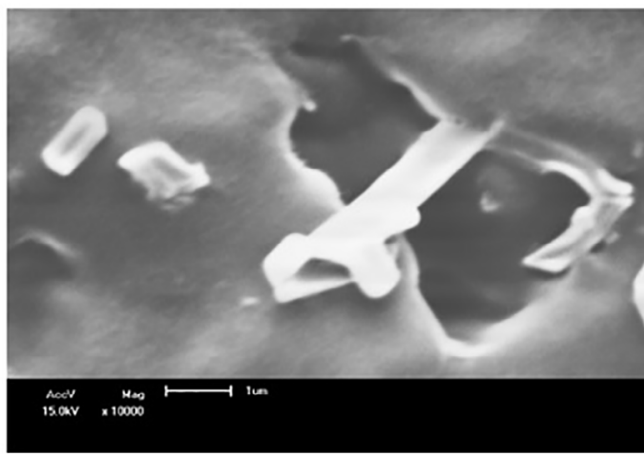

(c) $10000 x$

Figure 11. SEM images of PCL/PCL-g-MA/MMT in different magnifications, 500x, 5000x and 10000x.

\section{Conclusions}

PCL compounds upon addition of MMT and CLNa clays, and compatibilized with PCL-g-MA were successful melt extruded in this study, without evidences of degradation and particles aggregates during processing. Thermal resistance of PCL compounds was $20 \%$ higher as verified by thermogravimetry and heat distortion temperature, additionally clays acted as nucleant agent accelerating the melt crystallization. Tensile Strength was lightly changed meanwhile Elastic Modulus increased and Elongation was higher than $350 \%$ for all investigated compounds. Summing up, better performance of PCL was achieved that can be translated in wider applications and faster processing cycles, i.e. lower cost of processing/products.

\section{Acknowledgement}

To CNPq, to MCTI/CNPq, to Bentonit União Nordeste for the supply of clay, to the Polymer Materials Processing Laboratory/CCT/UFCG, to CAPES and CAPES/PNPD.

\section{References}

1. Sombrio BR, Schneider ALS, Pezzin APT, Apati G, Schroeder T. Produção de poli(3-hidroxibutirato) por Cupriavidus necator em batelada alimentada usando glicerol. Polímeros: Ciência e Tecnologia. 2017;27(spe):110-5.
2. Faria AU, Martins-Franchetti SM. Biodegradação de filmes de polipropileno (PP), poli(3-hidroxibutirato) (PHB) e blanda de PP/PHB por microrganismos das águas do Rio Atibaia. Polímeros: Ciência e Tecnologia. 2010;20(2):141-7.

3. Gross RA, Kalra B. Biodegradable polymers for the environment. Science. 2002;297(5582):803-7.

4. Vogelsanger N, Formolo MC, Pezzin APT, Schneider ALS, Furlan SA, Bernardo HP, et al. Blendas biodegradáveis de poli(3-hidroxibutirato) / poli(e-caprolactona): obtenção e estudo da miscibilidade. Materials Research. 2003;6(3):359-65.

5. Van Der Schueren LV, Meyer T, Steyart I, Ceylan Õ, Hemelsoet $\mathrm{K}$, Speybroeck VV, et al. Polycaprolactone and polycaprolactone/ chitosan nanofibers functionalised with the ph-sensitive dye Nitrazine Yellow. Carbohydrate Polymers. 2013;91(1):284-93.

6. França DC, Morais DD, Bezerra EB, Araújo EM, Wellen RMR. Photodegradation mechanisms on poly ( $\varepsilon$-caprolactone)(PCL). Materials Research. 2018;21(5):e20170837.

7. Hajiali F, Tajbakhsh S, Shojaei A. Fabrication and properties of polycaprolactone composites containing calcium phosphatebased ceramics and bioactive glasses in bone tissue engineering: a review. Polymer Reviews. 2018;58(1):164-207.

8. Van Der Schueren LV, Schoenmaker B, Kalaoglu ÖI, Clerck K. An alternative solvent system for the steady state electrospinning of polycaprolactone. European Polymer Journal. 2011;47(6):1256-63. 
9. Morais DDS, Siqueira DD, Luna CBB, Araújo EM, Bezerra EB, Wellen RMR. Grafting maleic anhydride onto polycaprolactone: influence of processing. Materials Research Express. 2019;1(5):1-19.

10. Muñoz PAR, Bettini SHP. Montmorillonite as support for peroxide in the melt grafting of maleic anhydride onto polypropylene. Journal of Applied Polymer Science. 2016;133(42):1-9.

11. Gonzaga VDM, Chrisostomo BA, Poli AL, Schmitt CC. Preparation, characterization and photostability of nanocomposite films based on poly (acrylic acid) and montmorillonite. Materials Research. 2018;21(4):e20171024.

12. Phua YJ, Chow WS, Ishak ZAM. Reactive processing of maleic anhydride-grafted poly(butylene succinate) and the compatibilizing effect on poly(butylene succinate) nanocomposites. Express Polymer Letters. 2013;7(4):340-54.

13. Montanheiro TLA, Passador FR, Oliveira MP, Durán N, Lemes AP. Preparation and characterization of maleic anhydride grafted poly (hydroxybutirate-CO-hydroxyvalerate)-PHBVg-MA. Materials Research. 2016;19(1):229-35.

14. Boesel LF. Nanocompósitos de poli(tereftalato de etileno) $e$ argila [dissertation]. São Carlos (SP): Federal University of São Carlos; 2001.

15. Almeida RKS. Hibridos inorgânico-orgânicos de vermiculita e aminas alifáticas ciclicas e acíclicas - adsorção e calorimetria [dissertation]. João Pessoa (PB): Federal University of Paraíba; 2008.

16. Siqueira DD, Morais DDS, Araújo EM, Luna CBB, Wellen RMR. Otimização da funcionalização de um polímero biodegradável utilizando planejamento fatorial. Revista Eletrônica de Materiais e Processos. 2017;12(3):192-8.

17. John J, Tang J, Yang Z, Bhattacharya M. Synthesis and characterization of anhydride-functional polycaprolactone. Journal of Polymer Science, Part A: Polymer Chemical. 1997;35(6):1139-48.

18. Manas-Zloczower I. Mixing and compounding of polymers: theory and practice. $2^{\text {nd }}$ ed. Munich: Hanser Publishers; 2009.

19. Aoki H, White JL, Fellers JF. A rheological and optical properties investigation of aliphatic (nylon 66, P $\gamma \mathrm{BLG}$ ) and aromatic (kelvar, nomex) polyamide solutions. Journal of Applied Polymer Science. 1979;23(8):2293-314.

20. Brito GF, Oliveira AD, Araújo EM, Melo TJA, Barbosa R, Ito EN. Nanocompósitos de polietileno/argila bentonita nacional: influência da argila e do agente compatibilizante PE-g-MA nas propriedades mecânicas e de inflamabilidade. Polímeros. 2008;18(2):170-7.

21. Gorrassi G, Tortora M, Vittoria V, Pollet E, Lepoittevin B, Alexandre M, et al. Vapor barrier properties of polycaprolactone montmorillonite nanocomposites: effect of clay dispersion. Polymer. 2003;44(8):2271-9.

22. Wu CS, Liao HT. Polycaprolactone-based green renewable ecocomposites made from rice straw fiber: characterization and assessment of mechanical and thermal properties. Industrial and Engineering Chemistry Research. 2012;51(8):3329-37.
23. Pattanayak A, Jana SC. Synthesis of thermoplastic polyurethane nanocomposites of reactive nanoclay by bulk polymerization methods. Polymer. 2005;46(10):3275-88.

24. Ayres E, Oréfice RL. Nanocompósitos derivados de dispersões aquosas de poliuretano e argila: influência da argila na morfologia e propriedades mecânicas. Polímeros. 2007;17(4):339-45.

25. AzeezAA, Rhee KY, Park SJ, Hui D. Epoxy clay nanocompositesprocessing, properties and applications: a review. Composites: Part B. 2013;45(1):308-20.

26. Santos PS. Ciência e tecnologia de argilas. $2^{\mathrm{a}}$ ed. São Paulo: Edgard Blücher Ltda; 1992. v. 2.

27. Paz RA, Leite AMD, Araújo EM, Melo TJA, Pessan LA, Passador FR. Propriedades mecânicas e reológicas de nanocompósitos de poliamida $6 \mathrm{com}$ argila organofílica nacional. Polímeros. 2013;23(5):682-89.

28. Kojuch LR. Membranas poliméricas obtidas a partir de nanocompósitos de PA6.6/Argila montmorilonítica pela técnica de inversão de fases [dissertation]. Campina Grande (PB): Federal University of Campina Grande; 2013.

29. Leite IF, Soares APS, Malta OML, Silva SML. Influência do tipo de argila no comportamento térmico dos nanocompósitos de PET. Revista Eletrônica de Materiais e Processos. 2013;8(2):80-6.

30. Silva MA, Tavares MIB, Nascimento SAM, Rodrigues EJR. Caracterização de nanocompósitos de poliuretano/ montmorilonita organofílica por RMN de baixo campo. Polímeros. 2012;22(5):481-5.

31. Vertuccio L, Gorrasi G, Sorrentino A, Vittoria V. Nano clay reinforced $\mathrm{PCL} /$ starch blends obtained by high energy ball milling. Carbohydrate Polymers. 2009;75(1):172-9.

32. Gautam S, Dinda AK, Mishra NC. Fabrication and characterization of PCL/gelatin composite nanofibrous scaffold for tissue engineering applications by electrospinning method. Materials Science and Engineering: C. 2013;33(3):1228-35.

33. Xing Z, Yang G. Crystallization, melting behavior, and wettability of poly (e-caprocatone) and poly (e-caprolactone)/ poly (N-vinylpyrrolidone) blends. Journal of Applied Polymer Science. 2010;115(5):2747-55

34. Rossetto E, Beraldin R, Penha FG, Pergher SB. Caracterização de argilas bentonitas e diatomitas e sua aplicação como adsorventes. Química Nova. 2009;32(8):2064-7.

35. Elzein T, Eddine MN, Delaite C, Bistac S, Dumas P. FTIR study of polycaprolactone chain organization at interfaces. Journal of Colloid and Interface Science. 2004;273(2):381-7.

36. Barbosa R, Araújo EM, Melo TJA, Ito EN. Preparação de argilas organofílicas e desenvolvimento de nanocompósitos de polietileno. Parte 2: Comportamento de inflamabilidade. Polímeros. 2007;17(2):104-12.

37. Araújo JR, Waldman WR, Paoli MA. Thermal properties of high density polyethylene composites with natural fibres: coupling agent effect. Polymer Degradation and Stability. 2008;93(10):1770-5.

38. Gao F. Clay/polymer composites: the story. Materials Today. 2004;7(11):50-5. 
39. Garcia-López D, Picazo O, Merino JC, Pastor JM. Polypropylene-clay nanocomposites: effect of compatibilizing agents on clay dispersion. European Polymer Journal. 2003;39(5):945-50.

40. Paiva LB, Morales AR, Guimarães TR. Propriedades mecânicas de nanocompósitos de polipropileno e montmorilonita organofílica. Polímeros. 2006;16(2):136-40.
41. Agrawal P, Araújo EM, Melo TJA. Desenvolvimento de nanocompósitos a partir de blendas com matriz de PA6. Polímeros. 2011;21(5):383-89.

42. Alves TS, Barbosa R, Angrizani CC, Coutinho MG, Carvalho LH, Canedo EL. Efeito do co-intercalante CIS-13-docosenamida na morfologia e propriedades mecânicas de compósitos polipropileno/argila organofílica. Polimeros. 2013;23(5):672-7. 